Review

\title{
COMMON RESPIRATORY DISEASES OF POULTRY IN BANGLADESH: A REVIEW
}

\author{
M.Z. Ali* \\ Animal Health Research Division, Bangladesh Livestock Research Institute \\ Savar, Dhaka 1341, Bangladesh
}

\begin{abstract}
Now-a-days, the poultry production in Bangladesh has become a sustainable and profitable industry. The poultry sectors are contributing to meet the national demand of proteins as well as implementing food security along with employment generation. The poultry industries are frequently affected by respiratory diseases. There are five viral respiratory diseases associated with respiratory systems such as Avian influenza (AI), Newcastle disease (ND), Infectious bronchitis (IB), Infectious laryngotracheitis (ILT), and Avian metapneumovirus (AE). Among them, Al outbreaks have been occurring regularly with changing genetic characters since 2007 and atotal of 556 Al outbreaks have been reported yet in Bangladesh that placed in most Al reporter countries. Bacterial diseases like Mycoplasmosis, Ornithobacterium rhinotracheale, Fowl cholera, and Infectious coryza are mostly prevalent respiratory diseases in Bangladesh. Mycoplasmosis is become a major threat for poultry industry especially Sonali (a cross-bred) type chickens due to poor biosecurity and breeding management. With respect to fungal diseases, Aspergillosis or brooder pneumonia is a highly prevalent respiratory disease in Bangladesh with causing pneumonia in young chickens. However, respiratory diseases are prevalent in higher rates and cause outbreaks frequently.
\end{abstract}

Keywords: Respiratory pathogen, Poultry, Avian influenza, Infectious bronchitis, Mycoplasmosis

\section{INTRODUCTION}

The avian respiratory system begins with nostril and ends with lungs and air sacs. It is divided into the upper and lower respiratory system (Tully, 1995). It acts as a major pathway for pathogen entry and key challenges for veterinarians to diagnose the disease properly (Baskerville, 1981). The etiology of most of the respiratory

\footnotetext{
* Corresponding author: zulfekar@blri.gov.bd
} 
diseases is very complex, and sometimes, co-infected with more than one pathogen leads to increase severity (Yashpal et al., 2004). The most serious and paramount important economic diseases of poultry are respiratory diseases (Roussan et al., 2008). A large number of pathogens such as bacteria, virus, and fungus are associated with respiratory infection. Viral diseases like Avian influenza (AI), Newcastle disease (ND), Infectious bronchitis (IB), Infectious laryngotracheitis (ILT)and Avian metapneumovirus; bacterial diseases like Mycoplasmosis, Ornithobacterium rhinotracheale, Fowl cholera and Infectious coryza; and fungal disease like Aspergillosis are responsible for causing respiratory diseases. Every pathogen has unique trends regarding their infection pattern, transmission, clinical symptoms, control strategy and vaccination (Ali, 2018). But often, they show similar clinical signs and become difficult to differentiate based on their lesions. It is assumed that management cost of respiratory diseases is higher than any other diseases (Nooruzzaman et al., 2019a). It is estimated that around US\$3,567.4 to US\$4,210.8 financial loss in breeder farms and US\$266.3 losses in broiler farms of 1000 birds flock in the USA occurred due to IB (Roussan et al., 2008). Similarly, around US\$ 7 million are lost because of Mycoplasma gallisepticum control program in poultry in the USA (Mohammed et al., 1987). In case of AI, financial loss increases when mortality reaches up to $100 \%$ (Nooruzzaman et al., 2019b).

The poultry industry of Bangladesh is now well established and sufficient enough to meet demand of meat (production 75.14 lakh MT vs demand (72.97 lakh MT) and very close to compete the demand of eggs (production1711 crores vs. demand 1732.64 crores) (DLS, 2019). Although the sector is flourishing day by day but the improvement hinders significantly by respiratory pathogens. The study aimed to describe the prevalence, risk factors and distribution of common respiratory diseases of poultry in Bangladesh.

\section{Avian influenza}

Avian influenza virus (AIV) is responsible for causing pandemic threat in 1918 as around 50 million peoples died all over the world due to Spanish flu (Luthy et al., 2018). In Bangladesh, the highly pathogenic avian influenza viruses (HPAIVs) were first identified in February 2007 from Bangladesh Livestock Research Institute (BLRI) (Biswas et al., 2008). Since then poultry industry in Bangladesh is facing a significant number of outbreaks waves each year. Bangladesh has been reported a total of 556 outbreaks since 2007 in OIE (OIE, 2020). The AIV has been isolated from multiple species including chickens, ducks, turkeys, goose, quails, pigeons, crows, migratory birds, humans, bats, and monkeys in Bangladesh (Nooruzzaman et al., 2019a; Nooruzzaman et al., 2019b). The virus mutated several times and changes its genetic clades from clade 2.2.2 to clade 2.3.2.1a. Now clade 2.3.2.1a is dominating over other clades from 2013 (Nooruzzaman et al., 2019a; Giasuddin et al., 2018a). Another clade 2.3.4.4 was also identified in 2016 for the HA gene of H5N6 (Giasuddin et al., 2018b). The AIV outbreaks are mostly seasonal in nature, 
especially more prevalent in winter and spring seasons rather than other seasons. The surveillance was conducted in the live bird market (LBM) in Dhaka and Chattogram city of Bangladesh and AIV was found nearly in all LBMs. Kim et al. (2018) reported, prevalence of $\mathrm{A}(\mathrm{H} 5)$ is higher in waterfowl than chickens and $\mathrm{A}(\mathrm{H} 9)$ is more prevalent in industrial chickens than waterfowl, and industrial broiler is more susceptible of $\mathrm{A}(\mathrm{H} 9)$ than indigenous breeds and cross-breads. They also observed both $\mathrm{A}(\mathrm{H} 5)$ and $\mathrm{A}(\mathrm{H} 9)$ in LBM environments. Rahman et al. (2020) reported, both $\mathrm{A}(\mathrm{H} 5)$ and $\mathrm{A}(\mathrm{H} 9)$ and/or their co-circulation present in the air of LBMs that pose serious public health issues. Therefore, LBMs of Bangladesh act as a potential source AIV transmission (Hasan et al., 2018). The veterinary hospital cases of AIV reported as 6.4\% in Chattogram (Sabuj et al., 2019), 5.4\% in Kishoreganj (Rahman et al., 2018), and 0.3\% in Dhaka district (Islam et al., 2014b). On the other hand, domestic ducks play a significant role to transfer AIV when they contact with migratory birds of Central Asian flyway in the wetland areas of Bangladesh (Barman et al., 2017). There are two vaccines (HVT-H5 and RE-6) against AIV that are licensed by Government in 2013 and it is using till now widely in parent stock farms but poor in marginal farms due to price and scarcity of vaccines (Giasuddin et al., 2018a).

\section{Newcastle diseases}

Newcastle disease (ND) is a viral endemic disease in poultry species in Bangladesh caused by Newcastle disease virus (NDV). It is the main constrains of backyard chickens farming and outbreaks may cause 100\% mortality (Chukwudi et al., 2012; Biswas et al., 2005) and decreased body mass and egg production of survived chickens (Alexander, 1992). Therefore, ND is directly linked with the rural economy and food safety as well as the nutritional safety of rural peoples as it causes high mortality and morbidity in backyard chickens. The prevalence rates of ND are varied in regions. Rahman et al. (2011) reported 17.50\% hospital cases were ND in Gazipur district and the highest prevalence was found in October and chickens age within 0-3 months (38.60\%). Badruzzaman et al. (2015) recorded, $13.84 \%$ of ND prevalence in Sylhet district. There were also more report of ND prevalence published like $11.24 \%$ in Bogura (Talukdar et al., 2017), 7.2\% in Dhaka (Giasuddin et al., 2002), 11\% in Chattogram (Biswas et al., 2005), 14.1\% in Dhaka division (Islam et al., 2014b), 25\% in Mymensingh (Rahman et al., 2012), 26.6\% in Kishoregonj (Rahman et al., 2018a), $11.78 \%$ in Kishoreganj (Mamun et al., 2019); 17.8\% in Ramu (Chattogram) (Sabuj et al., 2019). Regarding type of birds, the prevalence of NDV was recorded in layer $37.5 \%$, broiler $32.5 \%$, native bird $55.0 \%$ and duck $27.5 \%$ (Rahman et al., 2012). By genotype data, genotype XIII NDVs are under continuing evolution in Bangladesh along with genotype VI is circulating in the poultry species (Barman et al., 2017). The field veterinarians face symptoms like Viscerotropic velogenic Newcastle Disease (VVND) regularly. Vaccination is the only protective tools to prevent NDV and Government implementing vaccination strategy for three decades. But often it is failed due to unperformed, performed incorrectly, or performed irregularly and on the other hand, village indigenous chickens are rarely vaccinated (Abraham-Oyiguh et al., 2014). 


\section{Infectious bronchitis}

Infectious bronchitis is the most economic disease in poultry all over the world including Bangladesh caused by the Infectious bronchitis virus (IBV). It is highly contagious and causes increase mortality, low egg production, hatchability and egg quality, and increase medication cost (Bwala et al., 2018). The virus can be transmitted through aerosols and mortality could be varied from 40-90\%, and can affect chickens of all ages. Bhuyan et al. (2019a) reported an overall $17.52 \%$ prevalence of IBV in Bangladesh including $42.22 \%$ in a commercial layer, $17.24 \%$ in Sonali, $11.94 \%$ in broiler, and $14.93 \%$ in broiler breeder. Bhuyan et al. (2019b) also noted higher age of chickens (41-60 weeks) are prone to IB infection (54.55\%) and regarding season and flock size, winter and large flock are mostly susceptible for IB infection. According to location, IBV prevalence was $41.67 \%$ in Tangail, $24.42 \%$ in Mymensingh, $19.32 \%$ in Gazipur, $15.38 \%$ in Dhaka, $16.67 \%$ in Jamalpur, $13.68 \%$ in Bogura, 5.88\% in Cumilla, and 9.26\% in Rangpur (Barua et al., 2006a). Another study conducted by Bhuyan et al. (2018) revealed overall $59.30 \%$ seroprevalence of IBV in chickens of Bangladesh s including $23.82 \%$ in broiler, $97.87 \%$ in layer, $71.83 \%$ in Sonali and $83.46 \%$ in backyard chickens (Bhuyan et al., 2018). Bhuyan et al. (2019) reported overall $37.6 \%$ chickens are seropositive for IBV, whereas $31.4 \%$ in broiler and $60 \%$ in Sonali in 6 sub-districts of Mymensingh district. Several other studies also observed similar IBV seroprevalence in different districts of Bangladesh such as 58\% in Fatikchori (Chattogram district) (Barua et al., 2006b), 79.38\% in Northern region (Das et al., 2009), and 77.83\% in North-central region (Biswas et al., 2005). Veterinary hospital cases of IB reported as 1.3\% in Ramu (Cox's Bazar district) (Sabuj et al., 2019), 0.6\% in Kishoreganj (Rahman et al., 2018a). The S1 gene was sequenced by Bhuyan et al. (2019b) and phylogeny analysis demonstrated QX-like IBV and 4/91 strain of IBV were circulating in the chickens in Bangladesh. There are two types of imported vaccines available in Bangladesh, live and attenuated vaccines including H120, Ma5, 4/91, Massachusetts, and M41 strains (Ali and Hasan, 2018).

\section{Infectious Laryngotracheitis}

Infectious laryngotracheitis, highly contagious economically important viral disease of poultry caused by Gallidherpes virus. It is commonly known as Infectious laryngotracheitis virus (ILTV). Clinically the infected birds show gasping, extension of neck during inspiration, coughing bloody mucoid exudates, and mortality may reach up to $50 \%$ in adults, and recovered birds may act as a carrier for lifetime (Kirkpatrick et al., 2006). Rahman et al. (2018b) conducted a study in Gazipur district and reported an overall $81.47 \%$ ILTV seropositive chickens and older-aged birds were more prevalent. Another study carried out by Bhuyan et al. (2019a) in 6 sub-districts of Mymensingh revealed that ILTV was prevalent in Sonali birds (0.4\%). Jahan et al. (2012) observed 92.28\% ILTV seropositive chickens in 6 divisions of Bangladesh where $100 \%$ in Rajshahi, $84.37 \%$ in Rangpur, $100 \%$ in 
Chittagong, $100 \%$ in Khulna and $100 \%$ in Barisal Divisions. Similar type of study was done by Uddin et al. (2014) in commercial layer farm of 5 sub-district of Chattogram district reported $17.33 \%$ seroprevalence of ILTV whereas the highest $24 \%$ seropositive in the winter season and highest $23.24 \%$ in age between 10-35 weeks. Poor biosecurity and birds rearing in the deep litter were most susceptible for ILTV infection.

\section{Avian metapneumovirus (AMPV) or Swollen head syndrome}

Avian metapneumovirus is a viral disease of chicken and turkey commonly known as swollen head syndrome or avian pneumo-virus or avian rhinotracheitis caused by Avian metapneumovirus (AMPV), a virus belonging to Paramyxo viridae family with genus Metapneumovirus (Pringle, 1998). It is highly contagious disease infect upper respiratory tract showing symptoms like sneezing, coughing, nasal discharge, watery eyes, swollen head and wattles (Shin et al., 2000). The antibody against AMPV was first identified in Bangladesh during 2014 to 2016 by Ali et al. (2019) and reported overall $53.29 \%$ of birds in 5 districts were seropositive. They described seropositive bird's distribution as $70.07 \%$ in Gazipur, $41.26 \%$ in Bogura, $59.83 \%$ in Mymensingh, 53.44\% in Rangpur, and $39.40 \%$ in Panchagar district. They also demonstrated broiler breeder was higher $(72.30 \%)$ seropositive than layer $(50.85 \%)$ and Sonali $(35.57 \%)$ type chickens and on age groups adult age groups $>41$ weeks $(72.90 \%)$ and winter season $(68.21 \%)$ were shown higher seropositivity.

\section{Mycoplasmosis}

Mycoplasma is very tiny prokaryotes devoid of cell wall and covered by a plasma membrane, resistance to antibiotics, and usually host-specific (Razin et al., 1998). Mycoplasmosis is commonly caused by Mycoplasma gallisepticum (MG) and M. synoviae (MS), infect respiratory systems and show respiratory signs in chickens also known as chronic respiratory diseases (CRD) and infectious sinusitis in turkeys (Ali et al., 2017; Ali et al., 2015a). M. gallisepticum is a highly economically important disease of poultry industry due to its increased mortality, marked production losses, downgrading of the carcass, hatchability, long time medication cost. Approximately US\$ 7 million are lost for MG control program in the USA which represents a loss of US\$ 5 million in consumer surplus (Mohammed et al., 1987). The seroprevalence of MG was reported by Ali et al. (2017) in Bangladesh as overall seropositive rates $64.47 \%$ including $68.77 \%$ in Sonali, $63.74 \%$ in ISA brown, $59.37 \%$ in white leghorn layer type chickens. Adult age groups of chickens along with larger flock size, and the winter season were shown higher seropositivity of MG infection. Baura et al. (2006b) reported MG seropositivity in 53\% broiler and 73\% layer at Lohagara subdistrict and in $46 \%$ broiler and $60 \%$ layer at Satkania sub-district of Chattogram district. Islam et al. (2014a) reported 55.83\% MG seropositive chickens in Bhola district and higher prevalence was found in backyard chicken $(62.5 \%)$ than commercial chickens $(53.61 \%)$, pullet $(60.63 \%)$ shown higher positive than adults $(55.63 \%)$ and old aged $(51.25 \%)$ chickens and winter (60.42\%) compared to summer 
(51.25\%) season. The other researchers reported the prevalence of MG was $62.44 \%$ in Feni district (Sarkar et al., 2005), 55.13\% in Rajshahi district (Hossain et al., 2007), and 46.88\% Patuakhali district (Sikder et al., 2005). Mycoplasmosis was also noted in veterinary hospital cases such as $4.38 \%$ in Sylhet (Rahman and Adhikary, 2016), 11.66\% in Sylhet (Badruzzaman et al., 2015), 12.79\% in Bogura district (Talukdar et al., 2017), 4.8\% in Kishoregonj (Rahman et al., 2018), 7.6\% in Dhaka (Islam et al., 2014b), and 9.16\% in Kishoregonj (Mamun et al., 2019). The average prevalence of $M$. synoviae was found $60 \%$ in commercial breeder farms in Chattagram district and the highest prevalence was found in larger flock size (>10000), age group >60 weeks, and winter season as $70 \%, 70 \%$, and $64 \%$, respectively (Uddin et al., 2016).

\section{Ornithobacterium rhinotracheale (ORT)}

Ornithobacterium rhinotracheale (ORT) is a bacterial disease of poultry belongs to the family Flavobacteriaceae causes severe respiratory distress and associated with important economic losses by growth retardation, mortality, dropped egg production and egg quality (Allymehr, 2006). The ORT was first identified in Bangladesh in 2018 by Bhuiyan et al. (2019a), reported overall 45.9\% chickens were seropositive including $43.3 \%$ of broiler and 55\% of Sonali type chickens. By age, 5-20 weeks and 21-40 weeks of aged groups were found $38.3 \%$ and $90 \%$ seropositive for ORT, respectively.

\section{Fowl cholera}

Fowl cholera is an infectious bacterial disease of poultry caused by Pasteurella multocida and has been recognized as an economic disease worldwide. It can affect the respiratory system and shown symptoms like respiratory distress, cellulitis of face and wattles, mucous discharge from mouth and nose (Ali and Sultana, 2015). In the veterinary hospital cases, prevalence of fowl cholera was 3.1\% in Sylhet (Rahman and Adhikary, 2016), 2.2\% in Gazipur (Hassan et al., 2016), 3.90\% in Dhaka (Giasuddin et al., 2002), 5.26\% in Kishoregonj (Mamun et al., 2019), 6.76\% in northern and northcentral districts (Biswas et al., 2005), 2.7\% in Sylhet (Badruzzaman et al., 2015), 3.6\% in Kishoregonj district of Bangladesh (Sabuj et al., 2019).

\section{Infectious coryza}

Infectious coryza is acute, occasionally a chronic highly infectious bacterial disease of poultry caused by Haemophilus paragallinarum (Blackall and Reid, 1982). It can affect the upper respiratory tract of multi-aged birds characterized by catarrhal inflammation in the nasal and sinus mucosa, swollen wattles, dyspnea, sneezing with high morbidity and low mortality up to $20 \%$. Akter et al. (2013) reported $47.54 \%$ suspected samples were $H$. paragallinarum positive in the Northern region of Bangladesh during 2011-2012. They also found a prevalence of 52.8\% in laying hens, $42.8 \%$ in growing hens, and $16.6 \%$ in pre-laying stage. In the veterinary hospital survey, the incidence of infectious coryza was found $0.97 \%$ in Kishoregonj 
(Mamun et al., 2019), $0.2 \%$ in Gazipur (Hassan et al., 2016), and 2.4\% in Kishoregonj (Rahman et al., 2018a).

\section{Aspergillosis}

Aspergillosis is an infectious, non-contagious, ubiquitous opportunistic fungal infection of poultry caused by Aspergillus spp., responsible for causing respiratory distress in early life (Sultana et al., 2014). Overall 6.14\% chickens were found aspergillosis and the major risk factors are rainy season $(8.22 \%)$, birds age $(8.27 \%$ in 8-10 days old), use of sawdust (7.69\%) as litter (Sultana et al., 2014). There are many available incidence reports of Aspergillosis was recorded in the veterinary hospital, 7.33\% in Sylhet (Rahman and Adhikary, 2016), 0.33\% in northern and north-central districts (Biswas et al., 2005), 7.2\% in Sylhet (Badruzzaman et al., 2015), and 6.6\% in Kishoregonj (Sabuj et al., 2019).

\section{CONCLUSIONS}

The prevalence of respiratory diseases in both commercial and backyard chickens are higher in Bangladesh. It indicates poultry farming is more competitive regarding health management in Bangladesh. The formation of national standards for biosecurity guidelines and vaccination measures along with the strict implementation of biosecurity practices and proper vaccination could be a way of prevention of respiratory diseases in Bangladesh.

\section{REFERENCES}

Abraham-Oyiguh.J., Sulaiman, L.K., Meseko, C.A., Ismail, S., Suleiman, I., Ahmed, S.J. and Onate, E.C. (2014). Prevalence of Newcastle Disease Antibodies in Local Chicken in Federal Capital Territory. International Scholarly Research Notices, 1-3.

Akter, M.R., Khan, M.S. and Rahaman, M.M. (2013). Investigation on infectious coryza of layer chicken in Bangladesh with isolation, identification and antibiogram study. Scientific Journal of Veterinary Advances, 2(6):83-89.

Alexander, D. (1992). Paramyxoviridae, infection and immunity. Encyclopedia of Immunology, 63-99.

Ali, M, Z. and Hasan, B. (2018). Follow up of maternally derived antibodies titer against economically important viral diseases of chicken. Poultry Science Journal, 6(2): 149154.

Ali, M.Z. (2018). The seroprevalence study of Reticuloendotheliosis virus infection in chicken in Bangladesh. Egyptian Journal of Veterinary Science, 49(2): 179-86.

Ali, M.Z., Park, J.E. and Shin, H.J. (2019). Serological survey of avian Metapneumovirus infection in chickens in Bangladesh. Journal of Applied Poultry Research, 28(4):13301334.

Ali, M.Z., Rahman, M.M. and Sultana, S. (2015a). Seroprevalence of Mycoplasma gallisepticum antibody by ELISA and serum plate agglutination test of laying chicken. Veterinary World, 8(1): 9-14. 
Ali, M.Z. and Sultana, S. (2015b). Determination of humoral Immune response in chickens against Formalin-Inactivated Alum-Precipitated Fowl Cholera Vaccine. International Journal of Animal Biology, 1(4):114-117.

Ali, M.Z., Sultana, S., Karim, M.R., Hassan, M.Z., Yousuf, M.A., Hossen, A., Samad, M.A., Giasuddin, M. and Rahman, M.M. (2017). Compared the effect of indirect ELISA and serum plate agglutination (SPA) test for the detection of Mycoplasma gallisepticum in chicken. International Journal of Health, Animal Science and Food Safety, 4(1): 56-66.

Allymehr, M. (2006). Seroprevalence of Ornithobacterium rhinotracheale infection in broiler and broiler breeder chickens in west Azerbaijan province, Iranian Journal of Veterinary Medicine Series A, 53(1):40-42.

Badruzzaman, A.T., Noor, M., Mamun, M.A., Husna, A., Islam, K.M., Alam, K.J. and Rahman, M.M. (2015). Prevalence of diseases in commercial chickens at Sylhet Division of Bangladesh. International Clinical Pathology Journal, 1(5):00023.

Barman, L.R., Nooruzzaman, M., Sarker, R.D., Rahman, M.T., Saife, M.R.B., Giasuddin, M., Das, B.C., Das, P.M., Chowdhury, E.H. and Islam, M.R. (2017). Phylogenetic analysis of Newcastle disease viruses from Bangladesh suggests continuing evolution of genotype XIII. Achieve of Virology, 62(10):3177-3182.

Barman, S., Marinova-Petkova, A., Hasan, M.K., Akhtar, S., El-Shesheny, R., Turner, J.C., Franks, J., Walker, D., Seiler, J., Friedman, K. and Kercher, L. (2017). Role of domestic ducks in the emergence of a new genotype of highly pathogenic H5N1 avian influenza A viruses in Bangladesh. Emerging Microbes and Infection, 6(1):1-3.

Barua, H., Biswas, P.K., Anwar, M.N., Dey, B.C. and Debnath, M.C. (2006a). Serosurvey and isolation of infectious bronchitis virus in chickens reared in commercial and semiscavenging systems. Bangladesh Journal of Microbiology, 23(2): 114-117.

Barua, S.R., Prodhan, A.M., Islam, S. and Chowdhury, S. (2006b). Study on Mycoplasma gallisepticum in chickens in selected areas of Bangladesh. Bangladesh Journal of Veterinary Medicine, 4(2):141-142.

Baskerville A. (1981). Mechanisms of infection in the respiratory tract. New Zealand Veterinary Journal, 29(12): 235-238.

Bhuiyan, Z.A., Ali, M.Z., Moula, M.M., Bary, M.A., Arefin, N., Giasuddin, M. and Khan, Z.U.M. (2019a). Seroprevalence of major avian respiratory diseases in broiler and sonali chicken in selected areas of Bangladesh. Journal of Advance Veterinary and Animal Research, 6(4):561.

Bhuiyan, Z.A., Ali, M.Z., Moula, M.M., Giasuddin, M. and Khan, Z.U. (2019b). Prevalence and molecular characterization of infectious bronchitis virus isolated from chicken in Bangladesh. Veterinary World, 12(6): 909-915.

Bhuiyan, Z.A., Giasuddin, M. and Khan, Z.U. (2018). Seroprevalence of infectious bronchitis virus in different types of chicken in Bangladesh. Asian Journal of Medicine and Biomedical Research, 4(1):132-136.

Biswas, P.K., Biswas, D., Ahmed, S., Rahman, A. and Debnath, N.C. (2005). A longitudinal study of the incidence of major endemic and epidemic diseases affecting semiscavenging chickens reared under the Participatory Livestock Development Project areas in Bangladesh. Avian Pathology, 34: 303-312. 
Biswas, P.K., Christensen, J.P., Ahmed, S.S., Barua, H., Das, A., Rahman, M.H., Giasuddin, M., Hannan, A.S., Habib, M.A., Ahad, A. and Rahman, A.S. (2008). Avian influenza outbreaks in chickens, Bangladesh. Emerging Infectious Diseases, 14(12):1909.

Blackall, P.J. and Reid, G.G. (1982). Further characterization of Haemophilus paragallinarum and Haemophilus avium. Veterinary Microbiology, 7(4):359-367.

Bwala, D.G., Solomon, P., Duncan, N., Wandrag, D.B. and Abolnik, C. (2018). Assessment of Mycoplasma gallisepticum vaccine efficacy in a co-infection challenge model with QX-like infectious bronchitis virus. Avian Pathology, 47(3): 261-270.

Chukwudi, O.E., Chukwuemeka, E.D. and Mary, U. (2012). Newcastle disease virus shedding among healthy commercial chickens and its epidemiological importance. Pakistan Veterinary Journal, 32: 354-356.

Das, S.K., Khan, M.S.R. and Das, M. (2009). Seroprevalence of infectious bronchitis in chicken in Bangladesh. Bangladesh Journal of Veterinary Medicine, 7(1): 249-252.

DLS. (2019). Department of Livestock Services. Livestock Economy at a glance 2018-2019. Accessed at April 4, 2020.

Giasuddin, M., Ali, M.Z. and Karim, M.R. (2018a). Emergence of novel H5N6 avian influenza virus in Bangladesh. In Proceedings of the $24^{\text {th }}$ Annual Scientific Conference of Bangladesh Society for Veterinary Education and Research (BSVER), Mymensingh, Bangladesh, 24-25 March 2018.

Giasuddin, M., Ali, M.Z., Karim, M.R., Hassan, M.Z., Hasan, M. and Islam, E. (2018b). The past and present scenario of avian influenza and its control strategy in Bangladesh: A review. Bangladesh Journal of Livestock Research, 21-21: 24-28.

Giasuddin, M., Sil, B.K., Alam, J., Koike, I., Islam, M.R. and Rahman, M.M. (2002). Prevalence of poultry diseases in Bangladesh. Journal of Biological Sciences. 2(4):212-213.

Hassan, M.K., Kabir, M.H., Al Hasan, M.A., Sultana, S., Khokon, M.S. and Kabir, S.L. (2016). Prevalence of poultry diseases in Gazipur district of Bangladesh. Asian Journal of Medical and Biological Research, 2(1):107-112.

Hassan, M.M., Hoque, M.A., Ujvari, B. and Klaassen, M. (2018). Live bird markets in Bangladesh as a potentially important source for Avian Influenza Virus transmission. Preventive Veterinary Medicine, 156:22-27.

Hossain, K.M., Ali, M.Y. and Haque, M.I. (2007). Seroprevalence of Mycoplasma gallisepticum infection in chicken in the greater Rajshahi district of Bangladesh. Bangladesh Journal of Veterinary Medicine, 9-14.

Islam, M., Hassan, J. and Khan, M.S. (2014a). Seroprevalence of Mycoplasma gallisepticum infection in backyard and commercial layer chickens in Bhola district, Bangladesh. Journal of Advance Veterinary and Animal Research, 1(1):11-15.

Islam, S.S., Islam, S., Siddiqe, Z.F., Shawon, R.H., Hanif, S.M. and Rahman, M.A. (2014b). Diseases of Birds and their responses to treatment in different regions of Bangladesh. International Journal of Natural and Social Sciences, 1(1):31-36.

Jahan, M.S., Khan, M.F.R., Nazir, K.N.H., Amin, M.M. and Rahman, M.B. (2012). Serosurveillance of infectious laryngotracheitis in layer birds in Bangladesh. Microbes and Health, 1(2):38-40. 
Kim, Y., Biswas, P.K., Giasuddin, M., Hasan, M., Mahmud, R., Chang, Y.M., Essen, S., Samad, M.A., Lewis, N.S., Brown, I.H. and Moyen, N. (2018). Emerging Infectious Diseases, 24(12): 2309.

Kirkpatrick, N.C., Mahmoudian, A., Colson, C.A., Devlin, J.M. and Noormohammadi, A.H. (2006). Relationship between mortality, clinical signs and tracheal pathology in infectious laryngotracheitis. Avian Pathology, 35:449-453

Luthy, I.A., Ritacco, V. and Kantor, I.N. (2018). One hundred years after the" Spanish" flu. Medicina,78(2):113-118.

Mamun, M.A., Islam, K.M. and Rahman, M.M. (2019). Occurrence of poultry diseases at Kishoregonj district of Bangladesh. MOJ Proteomics and Bioinformatics, 8:7-12.

Mohammed, H.O., Carpenter, T.E. and Yamamoto, R. (1987). Economic impact of Mycoplasma gallisepticum and $M$. synoviae in commercial layer flocks. Avian Diseases, 1:477-82.

Nooruzzaman, M., Haque, M.E., Chowdhury, E.H. and Islam, M.R. (2019a). Pathology of clade 2.3. 2.1 avian influenza virus (H5N1) infection in quails and ducks in Bangladesh. Avian Pathology, 48(1): 73-79.

Nooruzzaman, M., Mumu, T.T., Hasnat, A., Akter, M.N., Rasel, M.S.U., Rahman, M.M., Parvin, R., Begum, J.A., Chowdhury, E.H. and Islam, M.R. (2019b). A new reassortant clade 2.3. 2.1 a H5N1 highly pathogenic avian influenza virus causing recent outbreaks in ducks, geese, chickens and turkeys in Bangladesh. Transboundary and Emerging Diseases, 66(5): 2120-2133.

OIE. 2020. World Health Organization for Animal Health. Highly pathogenic avian influenza, Bangladesh.

Pringle, C.R. (1998). Virus taxonomy-San Diego 1998.Archives of Virology, 143:1449-1459

Rahman, M., Hossain, M., Aktaruzzaman, M., Hossain, F. and Paul, S. (2011). Retrospective study of Newcastle disease: a cases of Gazipur in Bangladesh. International Journal of Sustainable Agriculture and Technology, 7(3):66-69.

Rahman, M., Mangtani, P., Uyeki, T.M., Cardwell, J.M., Torremorell, M., Islam, A., Samad, M.A., Muraduzzaman, A.K.M., Giasuddin, M., Sarkar, S. and Alamgir, A.S.M. (2020). Evaluation of potential risk of transmission of avian influenza A viruses at live bird markets in response to unusual crow die offs in Bangladesh. Influenza and Other Respiratory Viruses, 7.

Rahman, M.A. and Adhikary, G.N. (2016). Poultry diseases in some selected areas in Sylhet district of Bangladesh. Journal of Sylhet Agricultural University, 3(1):1-8.

Rahman, M.A., Rahman, M.M., Abdullah, M.S., Sayeed, M.A., Rashid, M.H., Mahmud, R., Belgrad, J.P. and Hoque, M.A. (2018a). Epidemiological assessment of clinical poultry cases through the government veterinary hospital-based passive surveillance system in Bangladesh: a case study. Tropical Animal Health Production, 51(4): 967-975.

Rahman, M.M., Uddin, M.K., Hassan, M.Z., Rahman, M.M., Ali, M.Z., Rahman, M.L., Akter, M.R. and Rahman, M.M. (2018b). Seroprevalence study of infectious laryngotracheitis virus antibody of commercial layer in Gazipur Districts of Bangladesh. Asian Journal of Medical and Biological Research, 4(1):1-6. 
Rahman, M.S., Rabbani, M.G., Uddin, M.J., Chakrabartty, A. and Her, M. (2012). Prevalence of Avian Influenza and Newcastle Disease Viruses in poultry in selected areas of Bangladesh using rapid antigen detection kit. Clinical and Infectious Diseases, 3(1):1-8.

Razin, S., Yogev, D. and Naot, Y. (1998). Molecular biology and pathogenicity of mycoplasmas. Microbiology and Molecular Biology Reviews, 62(4):1094-1156.

Roussan, D.A., Haddad, R. and Khawaldeh, G. (2008). Molecular survey of avian respiratory pathogens in commercial broiler chicken flocks with respiratory diseases in Jordan. Poultry Science, 87(3): 444-448.

Sabuj, A.A., Mahmud, T., Barua, N., Rahman, M.A., Islam, M.S. and Bary, M.A. (2019).Passive surveillance of clinical poultry diseases in an Upazila Government Veterinary Hospital of Bangladesh. African Journal of Microbiology Research, 13(29):632-639.

Sarkar, S.K., Rahman, M.B., Rahman, M., Amin, K.M.R., Khan, M.F.R. and Rahman, M.M. (2005). Sero-prevalence of Mycoplasma gallisepticum infection of chickens in model breeder poultry farms of Bangladesh. International Journal of Poultry Science, 4(1):32-35.

Shin, H.J., McComb, B., Back, A., Shaw, D.P., Halvorson, D.A. and Nagaraja, K.V. (2000). Susceptibility of broiler chicks to infection by avian pneumovirus of turkey origin. Avian Diseases, 44:797-802.

Sikder, A.J., Islam, M.A., Rahman, M.M. and Rahman, M.B. (2005). Seroprevalence of Salmonella and Mycoplasma gallisepticum infection in the six model breeder poultry farms at Patuakhali district in Bangladesh. International Journal of Poultry Science, 4(11):905-910.

Sultana, S., Rashid, S.M., Islam, M.N. and Ali, M.Z. (2014). Pathological investigation of avian aspergillosis in commercial broiler chicken at Chittagong district. International Journal of Advanced Research in Biological Sciences, 1(8):74-85.

Talukdar, M.L., Zuhra, F.T., Islam, K.E. and Ahmed, M.S. (2017). Prevalence of infectious diseases in Sonali chickens at Bogra Sadar Upazila, Bogra, Bangladesh. Journal of Advance Veterinary and Animal Research, 4(1):39-44.

Tully, T.N. (1995). Avian respiratory diseases: clinical overview. Journal of Avian Medicine and Surgery, 9(3): 162-174.

Uddin, M.I., Abid, M.H., Islam, M.S., Rakib, T.M., Sen, A.B., Chowdhury, S.M.Z.H., Anwar, M.N. and Kamaruddin, K.M. (2016). Molecular identification of Mycoplasma synoviae from seroprevalent commercial breeder farms at Chittagong district, Bangladesh. Veterinary World, 9(10):1063.

Uddin, M.I., Sen, A.B., Islam, M.S., Das, S., Sultana, N., Ripa, R.N., Kashem, A. and Kamaruddin, K.M. (2014). Sero-epidemiology of infectious Laryngotracheitis (ILT) in the commercial layer farms of Chittagong District, Bangladesh. Advance Animal and Veterinary Science, 2(6):316-320.

Yashpal S.M., Devi P.P. and Sagar M.G. (2004). Detection of three avian respiratory viruses by single-tube multiplex reverse transcription-polymerase chain reaction assay. Journal of Veterinary Diagnostic Investigation, 16: 244-248. 